\title{
Forest decline has not reduced genetic diversity of naturally regenerated Norway spruce from the Beskids, Poland
}

\author{
By E. Chomicz-Zegar ${ }^{*}$, J. A. NowaKowska ${ }^{1)}$ and A. Tereba ${ }^{1)}$
}

(Received $8^{\text {th }}$ December 2015)

\begin{abstract}
Norway spruce forests decline in the Beskids raises concerns about reduction of genetic variation in a next generation of forest. We aim to determine whether the genetic diversity in declining spruce stands was successfully transmitted to its self-seeded progeny. Using three nuclear microsatellite markers, we carried out the genetic assessment of naturally regenerated progeny and compered them with their maternal stands at an initial stage of decline. We investigated three spruce stands from the Śląski and Żywiecki Beskid and one primeval forest from the Tatras, as a reference. We noticed a high level of gene diversity, allelic richness and an effective number of alleles in progeny of all stands, without differences between declining stands from the Beskids and the primeval forest. The gene diversity was similar in maternal trees and their offspring. Higher gene diversity and generally higher number of alleles were noticed in young generation of stands. Genetic identity between generations was high in analyzed seed stands and the highest in the primeval forest. The results we presented indicate no significant effect of drastic reduction in the population size due to the forest decline on the level of genetic variation in self-seeded progeny of Norway spruce from the Beskids.
\end{abstract}

Key words: forest decline; genetic diversity; Norway spruce; Beskids; natural regeneration; primeval forest.

\section{Introduction}

Forest decline, as defined by CIESLA and DONAUBAUER (1994), is an episodic event characterized by premature, progressive loss of tree and stand vigour and health over a given period without obvious evidence of a single clearly

\footnotetext{
1) Molecular Biology Laboratory, Forest Research Institute, Sękocin Stary, Poland.

*) Corresponding author: ElżBIETA CHOMICZ-ZEGAR. Department of Mountain Forests, Forest Research Institute, Cracow, Poland.

E-Mail: E.Chomicz@ibles.waw.pl
}

identifiable casual factor. A decline has occurred in a number of tree species, simultaneously in different parts of the world (e.g. ScHULzE and Freer-SMith, 1990; UniYAl and UniYal, 2009). In Europe, Picea abies (L.) Karst. decline has been reported from Germany, Austria, Poland, the Czech Republic and Slovakia (HLÁSNY and TURC̆ÁNI, 2013). Artificial Norway spruce forests in the Beskids mountain range, straddling the borders of Slovakia, Poland and the Czech Republic, are among the most heavily damaged (HLÁsNy and SitKova, 2010). The death of spruce trees and stands occurs on vast continuous areas of the Beskids and leads to their deforestation (GRODZKI, 2010).

From a genetic perspective, forest decline means reduction of a population size, which can lead to decrease of genetic diversity in a next generation (LEIMU et al., 2006). Limited number of parent trees may promote selfing and biparental inbreeding among relatives leading to increased homozygosity in progeny generation. Additionally, some alleles, especially those occurring at a low frequency, can be lost by random genetic drift. Decline can also affect the gene flow and the mating system in a population by reduced stand density (FINKELDEY, 2002) and forest fragmentation (WHITE et al., 2002).

In this context concerns arise that just a part of gene pool of declining Norway spruce will be represented in naturally regenerated forests. Besides theoretical concepts, there is no empirical data on what extent forest decline shapes the genetic structures of a young generation of spruce from self-seeding. In fact, maintenance of high genetic diversity in progeny of declining stands will be crucial to fitness and adaptability of future forests.

Here we analyze genetic diversity in naturally regenerated progeny of declining spruce stands in the Beskids. Using nuclear microsatellite markers, we carried out the genetic assessment (sensu SCHWARTZ et al., 2006) of self-seeded progeny and compered them with their mater- 
nal stands at the initial stage of decline. We aim to determine whether the genetic variability in maternal trees was transmitted to progeny despite the forest decline. Moreover, we conducted analogical two-generations analysis of genetic diversity in a primeval spruce forest with no visible signs of decline. We hypothesized that transfer of genetic variability did not differ between populations from the Beskids and primeval forest. Otherwise, differences would be consequence of forest decline.

\section{Materials and Methods}

\section{Study site and sampling}

Research was conducted in Polish part of the Beskid Mountain Range (Beskid Ślaski and Żywiecki) in the Western Carpathians (Figure 1). Four Norway spruce stands with natural regeneration were analyzed, including three stands from the Beskids (Bukowiec, Zapowiedź, Skrzyczne) and one from the Tatra National Park (Wantule). The Beskid stands represented the most valuable provenances of Norway spruce in a whole range of the species (the Istebna provenance), some of them excluded from forest utilization as selected seed stands (Table 1). They were even-aged, pure spruce stands, artificially established in a place of primeval mixed forests with Silver fir, Common beech and Norway spruce. In 2010 these stands presented different stages of decline (see crown closure; Table 1). A stand from the Tatras was primeval spruce forest located in strict protection area. It was characterized by wide range of tree ages, both in maternal part of population and its progeny, with no visible signs of forest decline.

In each stand sets of 50 old (mature cohort) and 50 young (juvenile cohort) trees were sampled for genetic analysis. The old trees were sampled as putative mother trees, randomly at distance of $30-40 \mathrm{~m}$. The young trees were about $0,5 \mathrm{~m}$ high seedlings randomly chosen from naturally regenerated seedling patches. Sampling of mature cohort was done in the years 2007-2008 from trees without apparent symptoms of decline. Sampling of juvenile cohort was done in 2010 .

\section{Microsatellite analysis}

Total DNA was extracted from frozen needles using the DNeasy ${ }^{\circledR}$ Plant Mini Kit (QIAGEN). Three highly polymorphic nuclear microsatellite loci were chosen for this study: SpAG2, SpAC1H8, SpAGD1 (PFeIfFer et al., 1997). For PCR amplification some modifications of procedures in PFEIFFER et al. (1997) and YAZDANI et al. (2003) were adapted, as described below. Each reaction contained $0.15 \mu \mathrm{M}$ (SpAG2,

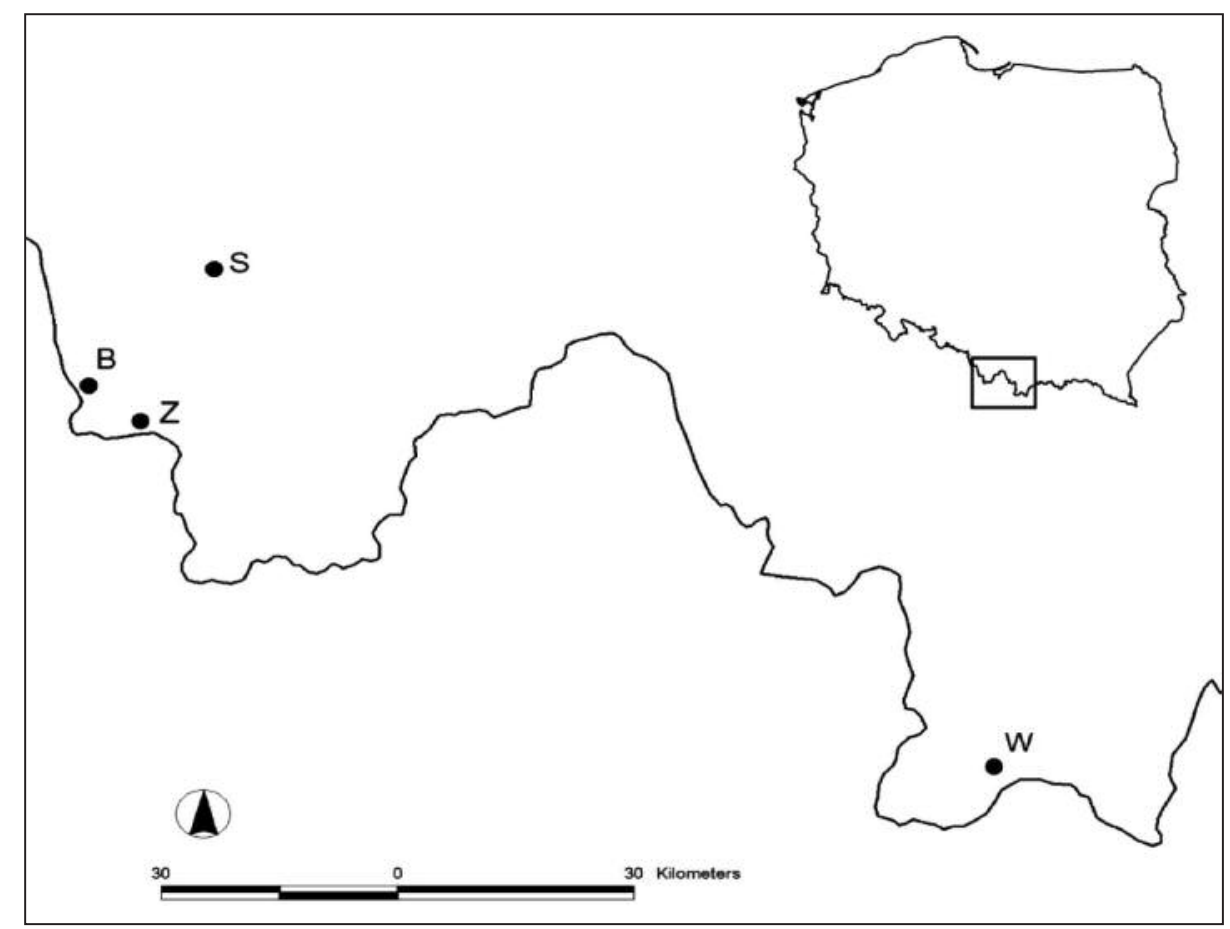

Figure 1. - Localization of investigated spruce stands. B, Bukowiec; Z, Zapowiedź; S, Skrzyczne; W, Wantule. 
Table 1. - Characteristics of Norway spruce stands analyzed in this study.

\begin{tabular}{|c|c|c|c|c|c|}
\hline Forest stand & $\begin{array}{l}\text { Lillitude/ } \\
\text { l ongitude }\end{array}$ & $\begin{array}{c}\text { Altitude, } \\
\text { masl }\end{array}$ & Age & Forest management & $\begin{array}{l}\text { Crown } \\
\text { closure }\end{array}$ \\
\hline Bukowice & $49^{\circ} 34^{\prime} / 18^{\circ} 59^{\prime}$ & $530-740$ & 170 & selected seed sland & low \\
\hline /apowied & $49^{\circ} 32^{\prime \prime} / 18^{\circ} 55^{\circ}$ & $580-690$ & 130 & selected seed stand & medium \\
\hline Skrzyczne & $49^{\circ} 40^{\prime} 19^{\circ} 02^{\prime}$ & $750-900$ & 120 & managed forest & medium \\
\hline Wantule & $49^{\circ} 14^{\prime} / 19^{\circ} 54^{\prime}$ & $1170-1350$ & 170 & strict nature reserve & dense \\
\hline
\end{tabular}

SpAGD1) or $0.24 \mu \mathrm{M}$ (SPAC1H8) F-primer and $0.135 \mu \mathrm{M}$ (SpAG2, SpAGD1) or $0.216 \mu \mathrm{M}$ (SPAC1H8) fluorescently labelled R-primers, $50 \mathrm{ng}$ of Picea abies genomic DNA, $2 \mathrm{mM} \mathrm{MgCl}$, $200 \mu \mathrm{M}$ dNTP mix, $0.03 \mathrm{U}$ Taq polymerase diluted with 1x PCR buffer and 1x Q-Solution (QIAGEN) to a total volume of $25 \mu \mathrm{l}$. PCRcycling conditions consisted of 1 cycle of 5 minutes with incubation at $95^{\circ} \mathrm{C}, 40$ cycles of $45 \mathrm{~s}$ of denaturation at $94^{\circ} \mathrm{C}, 45 \mathrm{~s}$ of annealing at $56^{\circ} \mathrm{C}(\mathrm{SpAG} 2, \mathrm{SpAGD} 1)$ or $60^{\circ} \mathrm{C}(\mathrm{SpAC} 1 \mathrm{H} 8)$, and $45 \mathrm{~s}$ of extension at $72^{\circ} \mathrm{C}$, with a final extension of 10 minutes at $72^{\circ} \mathrm{C}$, on a PTC-200 thermocycler (MJ Research). PCR products were separated on the CEQ 8000 automated sequencer (Beckman Coulter). Fragment sizes were determined with $\mathrm{CEQ}^{\mathrm{TM}} 8000$ Genetic Analysis System, software version 9.0 (Beckman Coulter). DNA Size Standard Kit - 400 (PN 608098, Beckman Coulter) was used.

Table 2. - Number of alleles in studied populations.

\begin{tabular}{|c|c|c|c|c|}
\hline \multirow{2}{*}{ Population } & \multicolumn{3}{|c|}{ Number of alleles per locus } & \multirow{2}{*}{$\begin{array}{l}\text { Vean number of alleles } \\
\text { per three loci }\end{array}$} \\
\hline & $\mathrm{SpAG2}$ & SPAC1H8 & SpAGDI & \\
\hline \multicolumn{5}{|l|}{ Bukowiec } \\
\hline Maternal (BM) & 16 & 26 & 34 & 25,3 \\
\hline Progeny (BP) & 14 & 29 & 39 & 27,3 \\
\hline \multicolumn{5}{|l|}{ Zilpowiedź } \\
\hline Matemal (ZM) & 18 & 28 & 37 & 27.7 \\
\hline Progeny (ZP) & 15 & 29 & 32 & 25,7 \\
\hline
\end{tabular}

Skrzyc7.ne

$\begin{array}{lllll}\text { Malemal (SM) } & 15 & 27 & 33 & 25.0 \\ \text { Progeny (SP) } & 15 & 32 & 39 & 28.7\end{array}$

Wantule

$\begin{array}{lllll}\text { Maternal (WM) } & 14 & 33 & 33 & 26.7 \\ \text { Progeny (WP) } & 15 & 28 & 41 & 33.0\end{array}$




\section{Statistical analysis}

The following statistical measures of genetic variation within populations were computed as average over loci with PopGen 1.31 (YEH et al., 1999): an effective number of alleles, $A_{\mathrm{E}}$; observed heterozygosity, $H_{\mathrm{O}}$; Nei's (1973) gene diversity, $D$; and Fstat 2.9.3 (GOUDET, 2002): allelic richness, $A R$; Wright's inbreeding coefficient, $F_{\text {IS }}$. Similarity of allele frequency distribution between maternal trees and their progeny per locus was analyzed with Fisher's exact test (FISHER, 1934) in SPSS Statistics 17.0 (Mehta and Patel, 2010). Genetic differentiation among mature and juvenile cohorts of each stand was measured by fixation index $F_{\mathrm{ST}}$ (WRIGHT, 1978) and Nei's (1978) genetic identity $I$ and genetic distance $D_{\mathrm{N}}$ with PopGen 1.31 (YEH et al., 1999).

\section{Results}

\section{Allele frequency}

Among highly polymorphic microsatellite markers selected for this study, the most polymorphic was locus SpAGD1 (70 alleles per 4 population), while the least polymorphic was locus SpAG2 (25 alleles per 4 population). There was different pattern in similarity of allele frequency distribution between maternal trees and its progeny in the spruce stands from the Beskids, and primeval forest of Wantule. In primeval population none of three loci showed significant differences between generations, while in each investigated stand from the Beskids significant differences were recorded for two loci (Table 3). In all studied stands

Table 3. - Similarity of allele frequency distribution between maternal populations $(\mathrm{M})$ and their progeny (P) - Fisher's exact test probability ( $p$-value) per locus.

\begin{tabular}{llll}
\hline Sample set & SpAG2 & SPAC1H8 & SpAGI) \\
\hline BM-BP & 0.919 & $<0.000$ & 0.020 \\
ZM-ZP & 0.001 & 0.102 & 0.047 \\
SM-SP & 0.000 & 0.072 & 0.008 \\
WM-WP & 0.462 & 0.085 & 0.861
\end{tabular}

BM-BP， ZM-ZP， SM-SP, WM-WP, comparisons between generations in Bukowiec, Zapowiedź, Skrzyczne and Wantule, respectively. changes in gene pool composition between mature and juvenile cohort were noticed. Several alleles, mainly those with low frequency, were found in maternal part of population but were not present in progeny and vice versa. In general, total number of alleles (Table 2), as well as effective number of alleles $\left(A_{\mathrm{E}}\right.$, Table 4$)$ was higher in progeny than in maternal trees. The only exception was forest stand in Zapowiedź with higher number of alleles in maternal generation. The slightest differences in number of alleles between mature and juvenile cohort were noticed in the primeval forest Wantule (4 alleles as regards total number of alleles per 3 loci; 0,588 as regards effective number of alleles $A_{\mathrm{E}}$ per 3 loci).

\section{Genetic variation}

High and similar level of genetic variation was observed in all analyzed populations, irrespective of level of forest naturalness. A summary of genetic variation measures per 3 loci is shown in Table 4. Mean allelic richness $(A R)$ ranged from 22.90 (ZP) to 25.63 (ZM). In com-

Table 4. - Summary of genetic variation parameters in maternal populations $(\mathrm{M})$ and their progeny $(\mathrm{P})$.

\begin{tabular}{|c|c|c|c|c|c|}
\hline Population & $A R$ & $A_{\text {卜 }}$ & $I I_{0}$ & $D$ & $\Gamma_{15}$ \\
\hline BM & 23.53 & 15000 & 0.854 & 0925 & 0.088 \\
\hline$B P^{3}$ & 24.86 & 17.726 & 0.833 & 0.930 & $0.114^{*}$ \\
\hline $\mathrm{ZM}$ & 25,63 & 16.193 & 0.786 & 0.912 & $0.150^{\circ}$ \\
\hline $\mathrm{ZP}$ & 22,90 & 14.373 & 0.724 & 0.920 & $0.223 \%$ \\
\hline $\mathrm{SM}$ & 23.47 & 14.293 & 0.799 & 0.878 & 0,100 \\
\hline $\mathrm{SP}$ & 25.37 & 15.890 & 0.894 & 0.924 & 0,043 \\
\hline WM & 24.95 & 15.270 & 0.730 & 0.919 & 0.217 \\
\hline WP & 24.72 & 15.858 & 0.833 & 0.924 & $0.109^{\circ}$ \\
\hline
\end{tabular}

B, Bukowiec; Z, Zapowiedź; S, Skrzyczne; W, Wantule. $A R$, allelic richness; $A_{\mathrm{E}}$, effective number of alleles; $H_{\mathrm{O}}$, observed heterozygosity; $D$, Nei's (1973) gene diversity; $F_{\text {IS }}$, inbreeding coefficient.

* Significant deviation from 0: $p<0.05$. 
Table 5. - Pairwise estimation of fixation index $\left(F_{\mathrm{ST}}\right)$, Nei's (1978) genetic distance $\left(D_{\mathrm{N}}\right)$ and genetic identity $(I)$ for maternal populations $(M)$ and their progeny $(P)$.

\begin{tabular}{llll} 
Sample set & $F_{\mathrm{ST}}$ & $D_{\mathrm{X}}$ & $I$ \\
\hline BM-BP & 0.008 & 0.156 & 0.855 \\
ZM-ZP & 0.010 & 0.197 & 0.822 \\
SM-SP & 0.032 & 0.810 & 0.455 \\
WM-WP & 0.006 & 0.077 & 0.926
\end{tabular}

BM-BP, ZM-ZP, SM-SP, WM-WP, comparisons between generations in Bukowiec, Zapowiedź, Skrzyczne and Wantule, respectively.

parison to maternal trees, allelic richness was higher in natural regeneration of Bukowiec $(+1.33)$ and Skrzyczne $(+1.90)$, lower in Zapowiedź $(-2.73)$ and almost the same in Wantule (-0.23). Mean gene diversity $(D)$ ranged from 0.878 (pop. SM) to 0.930 (pop. BP). In all analyzed stands, gene diversity was slightly higher in juvenile than in mature cohort. The biggest difference in gene diversity between generations occurred in the Skrzyczne forest stand (5\%).

Observed heterozygosity $\left(H_{0}\right)$ was lower than expected heterozygosity (gene diversity, $D$ ) in both mature and juvenile cohorts of all analyzed stands. Significant value of inbreeding coefficient $\left(F_{\text {IS }}\right)$ was noticed in two generations of stands in Zapowiedź and Wantule, as well as progeny of Bukowiec (Table 4). Heterozygote deficiency was higher in juvenile $(22 \%)$ than mature cohort (15\%) of Zapowiedź. Inversely in Wantule - maternal generation $(22 \%)$ revealed twice higher heterozygote deficiency than progeny $(11 \%)$. The lowest value of heterozygote deficiency was noticed in progeny of forest stand in Skrzyczne (4\%).

\section{Genetic differentiation and gene flow}

High genetic similarity was found between generations of forest stands in Bukowiec, Zapowiedź and Wantule. Low value of genetic distance $\left(D_{\mathrm{N}}\right)$ and fixation index $\left(F_{\mathrm{ST}}\right)$ between mature and juvenile cohort were noticed in these three stands (Table 5). The highest genetic identity $(I)$ between generations was noticed in the primeval forest - Wantule (93\%). Slightly lower values of identity occurred in selected seed stands in Bukowiec (86\%) and
Zapowiedź (82\%). The highest genetic distance $\left(D_{N}=81 \%\right.$, Table 5) and the lowest genetic identity $(I=46 \%)$ between mature and juvenile cohort occurred in managed stand in Skrzyczne. The highest fixation index $\left(F_{\mathrm{ST}}=3,2 \%\right)$, few times higher than in the rest of analysed stands, was also noticed in Skrzyczne.

\section{Discussion}

The results we obtained in this study show that genetic variation of declining spruce stands in the Beskids was successfully conserved in self-seeded progeny of these stands. We noticed a high level of gene diversity $(D)$, observed heterozygosity $\left(H_{\mathrm{O}}\right)$, allelic richness $(A R)$ and a high effective number of alleles $\left(A_{\mathrm{E}}\right)$ in naturally regenerated progeny of all analysed stands, without any differences between progeny of declining spruce stands from the Beskids (Bukowiec, Zapowiedź, Skrzyczne, $D=0.930$, $0.920,0.924, H_{\mathrm{O}}=0.833,0.724,0.894, A R=$ $24.86,22.90,25.37, A_{\mathrm{E}}=17.726,14.373,15.890$, respectively) and seedlings growing under canopy of the primeval forest (Wantule, $D=$ $\left.0.924, H_{\mathrm{O}}=0.833, A R=24.72, A_{\mathrm{E}}=15.858\right)$. This is in line with the results of GöMÖRY (1992) and WeHENKEL et al. (2009), who did not confirm the hypothesis of a positive correlation between naturalness and genetic diversity of forest stand. Calculated parameters of genetic variation in all populations were similar to those obtained by NowAKOWSKA (2009) with the same set of microsatellite loci in 20 populations of Norway spruce representing the whole range of the species in Poland (average 20 populations $\left.A_{\mathrm{E}}=16.165 ; H_{\mathrm{S}}=0.933 ; H_{\mathrm{T}}=0.851\right)$. The high genetic variation is a hallmark of Norway spruce, determined by ecological and reproductive characteristics of the species (HAMRICK et $a l$. , 1992). According to HAMRICK (2004), specific features of forest trees, such as longevity, dominance of cross-fertilization, high fecundity and effective gene flow through pollen and seeds are responsible for maintenance of high genetic variation in declining forest trees populations, even in case of drastic reduction in the population size. No significant changes were also found in the natural genetic variation of tropical tree species Cordia africana, despite a sharp reduction in species occurrence as a result of deforestation, forest fragmentation and selective logging (DERERo et al., 2011).

Gene diversity $(D)$ of the analysed stands was similar in maternal trees and their progeny, 
which is consistent with other results obtained in Norway spruce. MAGHULY at al. (2006) analysed microsatellite polymorphism of mature trees (70-100 years old) and their natural regeneration (6-10 years old) in 3 Norway spruce stands in Austria. In all cases expected heterozygosity was only slightly higher in maternal trees $\left(H_{\mathrm{E}}=0.8173,0.8488\right.$ and 0.8356 , respectively) than in progeny $\left(H_{\mathrm{E}}=0.7596\right.$, 0.7658 and 0.8106 , respectively). Similar results were obtained by NowAKOWskA et al. (2014b) for two generations of a single managed spruce stand in Poland $\left(H_{\mathrm{E}}=0.922\right.$ in mature cohort, $H_{\mathrm{E}}=0.913$ in juvenile cohort). WoJNICKAPó́tTorak at al. (2013) found relatively similar levels of genetic variation between three age classes (4-10 years old; 11-100 years old, and 100 years old) of naturally regenerating spruce population in Białowieża Primeval Forest, Poland. Very slight differences in the level of heterozygosity were also noticed between mature Norway spruce stands and seed lots originating from these stands (KONNERT, 2009; NASCIMENTO et al., 2010). Furthermore, little differentiation occurred among spruce populations and among pollen allele frequencies of single seed tree within populations (FINKELDEY, 1995). Comparable diversity of a mature tree and its self-seeded progeny gene pools was found also in Scots pine (Pinus sylvestris; KosINSKA et al., 2007; NoWAKOWSKA et al., 2014b), Douglas fir (Pseudotsuga menziesii; ADAMs et al., 1998), white spruce (Picea glauca; RAJORA, 1999), Dragon spruce (Picea asperata; WANG et al., 2010), common beech (Fagus sylvatica; KONNERT, 2010; SUlKOWSKA and NowAKOWSKA, 2011) and oaks (Q. petraea and Q. robur; CHYBICKI and BURCZYK, 2010; DERING and CHYBICKI, 2012; NowAKOWSKA et al., 2014a). In this context, we can conclude that conservation status of gene pool of declining spruce stands from the Beskids in the next generation from self-seeding does not differ from that described for other spruce stands as well as naturally regenerating stands of other mentioned species.

In the presented study, we noticed higher gene diversity $(D)$ and higher number of alleles (except forest stand in Zapowiedź) in young generation of the analysed stands, indicating that pollination probably involved also trees from outside the investigated population. The biggest difference in gene diversity between mature and juvenile cohort occurred in
Skrzyczne (5\%). Low genetic identity $(44.5 \%)$ between generations, as well as low inbreeding coefficient in progeny of Skrzyczne $\left(F_{\text {IS }}=\right.$ 0.043), also indicates considerable contribution of spruce trees from outside the local population to reproduction of this stand. Intensive, longdistance gene flow is characteristic of spruce, in which transport of both pollen and seeds is held by wind. In case of Skrzyczne an external pollen flow could be further promoted by the process of spruce decline, significantly advanced in this stand. During the sampling of progeny, the maternal part of population was represented only by thin strip of old trees, while offspring occurred mostly on the adjacent open area. Compared with continuous forest, the gene flow in open landscape due to the forest fragmentation can be intensified by increase in the frequency of long-distance pollen movement (WHITE et al., 2002). In forest trees it was observed, that immigration of pollen and seeds from outside the local population prevents reduction of genetic variability in next generation, even if a significant reduction in number of maternal trees occurred (LOWE et al., 2005; KRAMER et al., 2008; BACLES and JUMP, 2011). In case of Norway spruce in the Beskids, it can be also hypothesized that the potential effects of genetic drift and inbreeding resulting from forest decline were counterbalanced by predominantly outcrossing mating system and a high gene flow from the residual and surrounding trees.

The gene pool enrichment of the Skrzyczne progeny generation, due to the immigration of pollen and seeds from outside the local population, should be seen as an advantageous phenomenon with regard to the demand for maintaining the highest genetic variation in forest trees populations. The positive result of an external gene flow could be the lowest heterozygote deficiency among all studied stands noticed in offspring of Skrzyczne (4\%). On the other hand, the intensive gene flow from adjacent forest stands causes the gene pools of mature and juvenile cohort, characterized by specific alleles and genotypes frequencies, are quite distinct from each other. The highest genetic distance between mother stand and its progeny was noticed in Skrzyczne $\left(D_{\mathrm{N}}=0,810\right)$, as well as genetic divergence several times higher than in the rest of the analysed stands $\left(F_{\mathrm{ST}}=0,032\right.$; while: Bukowiec $F_{\mathrm{ST}}=0,008$; Zapowiedź $F_{\mathrm{ST}}=0,010$; Wantule $\left.F_{\mathrm{ST}}=0,006\right)$. 
In Skrzyczne, natural regeneration reflects only $45 \%$ of mother stand gene pool. Gene flow from neighbouring stands causes gene pools of mature and juvenile cohorts are not identical also in the rest of investigated stands. However, genetic identity between generations in analyzed seed stands, was very high (Bukoweic $86 \%$, Zapowiedź $82 \%$ ) and the most genetically similar was mother stand and its natural regeneration in the primeval forest (Wantule, 93\%). Observed genetic similarity between generations in the studied seed stands allows to expect that beneficial features of the elite spruce provenance Istebna have been largely transmitted to the offspring.

The gene pool of progeny in Skrzyczne was the most enriched among investigated populations, however gene diversity in natural regeneration of this stand (Skrzyczne $D=0.924$ ) was similar (Bukowiec $D=0.930$; Zapowiedź $D=$ 0.920 ) or equal (Wantule $D=0.924$ ) to the estimated in progeny of all analysed stands. Observed difference then was related to lower heterozygosity in maternal trees (Skrzyczne $D=$ 0.878 , while: Bukowiec $D=0.925$; Zapowiedź $D$ $=0.912$; Wantule $D=0.912$ ). One can explain lower heterozygosity in maternal trees of Skrzyczne by unintentional genetic changes caused by silvicultural practices (SAVOLAINEN and KÄRKKÄINEN, 1992; FINKELDAY and ZIEHE, 2004), as Skrzyczne was the only managed stand among all analysed. It should be noted, however, that no convincing evidence of negative impact of forest management on population genetic diversity of forest trees has been found so far (KRAKOWSKI and EL-KASSABY, 2004; KONNERT, 2010; FAGERIA and RAJORA, 2013).

On the contrary, some authors suggest the mating system in unmanaged forests can be characterized by inbreeding resulted from more frequent mating between relatives (NEALE and ADAMS, 1985; LEDIG, 1992). WANG et al. (2010) observed the genetic diversity of naturally regenerated Dragon spruce (Picea asperata) was significantly lower in the primeval, more than 300 year old forest, than in managed stands. In beech forests (Fagus sylvatica) BUITEVELD et al. (2007) noticed that inbreeding was slightly but significantly higher in the limited-managed stands than in the stands with high management intensity. Likewise in the present study, inbreeding coefficient $\left(F_{\text {IS }}\right)$ of two generations of spruce in the primeval forest Wantule (WM 0,217; WP 0,109) was signifi- cantly different from zero, and higher than in majority of spruce populations from the Beskids (BM 0,088; BP 0,114; SM 0,100; SP 0,043). Taking into account, the largest amounts of spruce seeds are produced through cross-fertilization (BURCZYK et al., 2004), the observed inbreeding is likely to be the result of mating between relatives within the population. Among the analyzed stands the lowest genetic distance $\left(D_{\mathrm{N}}\right.$ $=0,077)$ and genetic divergence $\left(F_{\mathrm{ST}}=0,006\right)$ between two generations also indicate a small proportion of genes from outside the local population in the genetic pool of young generation of Wantule. Moreover, Wantule was the only stand in which allele frequency distribution in mature and juvenile cohort did not differ significantly from each other in all analysed microsatellite loci. The question remains whether potentially more frequent mating between relatives is connected with protection status of Wantule (strict nature reserve) or rather with its location in the upper mountain zone characterized by extreme environmental conditions. Difficulties with flowering caused by low temperatures and short growing season as well as spatial isolation of population due to specific terrain configuration can result in limitation the amount of pollen available for cross-fertilization. A slight excess of homozygous genotypes at high altitude populations of forest trees was also observed in European larch (Larix decidua) and Stone pine (Pinus cembra) from the Alps (LeWANDOWSKI and BURCZYK, 2000).

Ultimate objective of our study was to quantify short-term consequences of forest decline for the genetic variation of Norway spruce in the next generation. The results we presented indicate no significant effect of drastic reduction in the population size due to the disastrous Norway spruce dieback on transfer of genetic diversity between two generations of spruce forest stand in the Beskids. It is possible that sowing occurred in the initial phase of forest decline, so that most of the trees forming a parental part of population took part in the reproduction process. On the other hand, the potential loss of genetic diversity can be compensated by the gene flow between adjacent forest stands, intensified due to reduction of stands density and forest fragmentation. It is worth noting, however, that presented analysis concerns a mother stand and a natural regeneration only in juvenile phase, while some changes in genetic structure of population can be detected only in a long term perspective (LEDIG, 1992; BACLES and 
JUMP, 2011). In this connection, genetic structure of natural regeneration in older age as well as in future generations should be monitored. Further research on genetic variation and mating system in primeval forests, excluded from any management activities, are also needed.

\section{Acknowledgments}

The authors thank Prof. STANisLAW NiEMtuR for inspiration, MARIUSZ KAPSA and MAREK PIERZCHAXA for collecting samples in the Tatra National Park, as well as JOLANTA BIENIEK for invaluable laboratory assistance. This work was supported by the State Forests National Forest Holding in Poland under Grants BLP-340 and BLP-309.

\section{References}

Adams, W. T., J. H. Zuo, J. Y. Shimizu and J. C. TAPPEINER (1998): Impact of alternative regeneration methods on genetic diversity in coastal douglas-fir. For Sci 44: 390-396.

Bacles, C. F. E. and A. S. Jump (2011): Taking a tree's perspective on forest fragmentation genetics. Trends Plant Sci 16: 13-18.

Buiteveld, J., G. G. Vendramin, S. Leonardi, K. KAMER and T. GEBUREK (2007): Genetic diversity and differentiation in European beech (Fagus sylvatica L.) stands varying in management history. For Ecol Manage 247: 98-106.

BurCZYK, J., A. LeWANDOWSKI and W. CHALUPKA (2004): Local pollen dispersal and distant gene flow in Norway spruce (Picea abies (L.) Karst). For Ecol and Manage 197: 39-48.

Chybicki, I. J. and J. BurczyK (2010): Realized gene flow within mixed stands of Quercus robur L. and Q. petraea (Matt.) L. revealed at the stage of naturally established seedling. Mol Ecol 19: 2137-2151.

Ciesla, W. M. and E. Donaubauer (1994): Decline and dieback of trees and forests: a global overview. FAO Forestry Paper 120, Rome, Italy: FAO.

Derero, A., O. Gailing and R. Finkelday (2011): Maintenance of genetic diversity in Cordia africana Lam., a declining forest tree species in Ethiopia. Tree Genet Genomes 7: 1-9.

Dering, M. and I. CHYBICKI (2012): Assessment of genetic diversity in two-species oak seed stands and their progeny populations. Scand J For Res 27: 2-9.

FAGERIA, M. S. and O. P. RAJORA (2013): Effects of harvesting of increasing intensities on genetic diversity and population structure of white spruce. Evol Appl 6(5): 778-794.

FISHER, R. A. (1934): Statistical methods for research workers. $5_{\text {th }}$ ed. Edinburgh: Oliver and Boyd.
FinKELDEY, R. (1995): Homogeneity of pollen allele frequencies of single seed trees in Picea abies (L.) Karst. plantations. Heredity 74: 451-463.

FinKELDEY, R. (2002): Reproduction in continuous cover forests - the geneticist's perspective. In: VON GADOW, K., NAGEL, J., SABOROWSKI, J., editors. Continuous Cover Forestry. Assessment, Analysis, Scenarios. Dordrecht, The Netherlands: Kluwer Academic Publishers; p. 67-79.

FinKELDEY, R. and M. ZiEHE (2004): Genetic implications of silvicultural regimes. For Ecol Manage 197: 231-244.

GouDET, J. (2001): FSTAT, a program to estimate and test gene diversities and fixation indices (version 2.9.3) from http://www2.unil.ch/popgen/softwares/fstat.htm

GÖMÖRY, D. (1992): Effect of stand origin on the genetic diversity of Norway spruce (Picea abies Karst.) populations. For Ecol Manage 54: 215-223.

GrodZKI, W. (2010): The decline of Norway spruce Picea abies (L.) Karst. stands in Beskid Śląski and Żywiecki: theoretical concept and reality. Beskydy 3(1): 1926.

HAMRICK, J. (2004): Response of forest trees to global environmental changes. For Ecol Manage 197: 323-335.

Hamrick, J. L., M. J. W. GodT and S. L. ShermanBROYLes (1992): Factors influencing levels of genetic diversity in woody plant species. New For 6: $95-124$.

HEDRICK, P. W. (2001): Conservation genetics: where are we now? Trends Ecol Evol 16: 629-636.

HlÁsNY, T. and Z. SitKovÁ (2010): Spruce forest decline in the Beskids. Zvolen, Slovakia: National Forest Centre.

HLÁSNY, T. and M. TuRČ́ÁNI (2013): Persisting bark beetle outbreak indicates the unsustainability of secondary Norway spruce forests: case study from Central Europe. Ann For Sci 70: 481-491.

Konnert, M. (2009): Genetic variation of Picea abies in southern Germany as determined using isozyme and STS markers. Dendrobiology 61: 131-136.

KonNERT, M. (2010): Contribution of forest genetics for a sustainable forest management. In: SABOR, J., editor. Postęp badań w zakresie genetyki populacyjnej i biochemicznej drzew leśnych. Prace Komisji Nauk Rolniczych, Leśnych i Weterynaryjnych PAU 13: 67-78.

Korshikov, I. I. and E. A. MudrIK (2006): Age dynamics of genetic variation in an isolated population of Chalk pine Pinus sylvestris var. Cretacea Kalenicz. Ex. Kom. From Donbass. Russ J Genet 42: 532-538.

Kosinska, J., A. LeWANDowski and W. ChalupkA (2007): Genetic variability of Scots pine maternal populations and their progenies. Silva Fenn 41: 5-12.

KRAKOWSKI, J. and Y. A. EL-KASSABY (2004): Impacts of alternative silviculture systems on mating systems and genetic diversity of forest tree species. In: BEAULIEU, J., editor. Silviculture and the conservation of genetic resources for sustainable forest 
management. Proceedings of the symposium of the North American forest commission, forest genetic resources and silviculture working groups, and the International Union of Forest Research Organizations (IUFRO); 2003 September 21; Quebec City, Canada: Natural Resources Canada, Canadian Forest Service; p. 75-87.

Kramer, A. T., J. L. Ison, M. V. Ashley and H. F. Howe (2008): The paradox of forest fragmentation genetics. Conserv Biol 22: 878-885.

LEDIG, F. T. (1992): Human impacts on genetic diversity in forest ecosystems. Oikos 63: 87-108.

Leimu, R., P. MUTIKAINEN, J. KoRICheva and M. Fischer (2006): How general are positive relationships between plant population size, fitness and genetic variation? J Ecol 94(5): 942-952.

LEWANDOWKI, A. and J. BuRczYK (2000): Mating system and genetic diversity in natural populations of European larch (Larix decidua) and Stone pine (Pinus cembra) located at higher elevations. Silvae Genet 49: 158-161.

Lowe, A. J., D. Boshier, M. Ward, C. F. E. Bacles and C. NAVARRO (2005): Genetic resource impacts of habitat loss and degradation: reconciling empirical evidence and predicted theory for neotropical trees. Heredity 9: 255-273.

Maghuly, F., W. Pinsker, W. Praznik and S. Fluch (2006): Genetic diversity in managed subpopulations of Norway spruce [Picea abies (L.) Karst.]. For Ecol aManage 222: 266-271.

Mehta, C. R. and N. R. PAtel (2010): IBM SPSS exact tests. Cambridge, USA: SPSS Inc.

Nascimento, S., O. Gailing, R. Finkeldey, M. Ziehe and H. H. HATTEMER (2010): Reproduction system of Norway spruce (Picea abies [L.] Karst.) in pure and mixed stands with different density. Forstarchiv 81: 218-227.

Neale, D. B. and W. T. AdAms (1985): The mating system in natural and shelterwood stands of Douglas-fir. Theor Appl Genet 71: 201-207.

NEI, M. (1973): Analysis of gene diversity in subdivided populations. Proc Natl Acad Sci USA 70: 3321-3323.

NEI, M. (1978): Estimation of average heterozygosity and genetic distance from a small number of individuals. Genetics 89: 583-590.

NowAKowskA, J. A. (2009): Mitochondial and nuclear DNA differentiation of Picea abies populations in Poland. Dendrobiology 61: 119-129.

Nowakowska, J. A., A. Michalska and T. ZACHARA (2014a): Zmiany w strukturze genetycznej naturalnego odnowienia dębu (Quercus petraea [Matt.] Liebl.) w odniesieniu do drzew matecznych. Sylwan 158: 83-89.

Nowakowska, J. A., T. ZaChara and A. KoneckA (2014b): Genetic variability of Scots pine (Pinus sylvestris L.) and Norway spruce (Picea abies L. Karst.) natural regeneration compared with their maternal stands. For Res Pap 75(1): 47-54.

Pfeiffer, A., A. M. Olivieri and M. Morgante (1997): Identification and characterization of microsatellites in Norway spruce (Picea abies K.). Genome 40: 411-419.

RAJORA, O. P. (1999): Genetic biodiversity impacts of silvicultural practices and phenotypic selection in white spruce. Theor Appl Genet 99: 954-961.

SAVOLAINEN, O. and K. KÄRKKÄINEN (1992): Effect of forest management on gene pools. New For 6: $329-345$.

SHEA, K. L. (1990): Genetic variation between and within populations of Engelmann spruce and subalpine fir. Genome 33: 1-8.

Schulze, E. D. and P. H. Freer-Smith (1990): An evaluation of forest decline based on field observations focused on Norway spruce, Picea abies. Proc R Soc Edinb Biol Sci 97: 155-168.

Schwartz, M. K., G. LuikarT and R. S. WAPLES (2006): Genetic monitoring as a promising tool for conservation and management. Trends Ecol Evol 22: 25-33.

SuŁkowska, M. and J. NowAKowska (2011): Genetic structure of European beech of mother and progeny stands in Poland on the basis of DNA chloroplast markers. For Ideas 17: 21-26.

UNIYAL, S. K. and A. UNIYAL (2009): Climate change and large-scale degradation of spruce: common pattern across the globe. Clim Res 38: 261-263.

WANG, Z.-S., H. LiU, W.-X. XU, N. WeI and S. Q. AN (2010): Genetic diversity in young and mature cohorts of cultivated and wild populations of Picea asperata Mast (Pinaceae), a spruce endemic in western China. Eur J For Res 129: 719-728.

Wehenkel, C., J. J. Corral-Rivas, H. A. CastelLANos-Bocaz and A. Pinedo-Alvarez (2009): Is there a positive relationship between naturalness and genetic diversity in forest tree communities? Investigación Agraria: Sistemas y Recursos Forestales 18: 20-27.

White, G. M., D. H. Boshier and W. Powell (2002): Increased pollen flow counteracts fragmentation in a tropical dry forest: An example from Swietenia humilis Zuccarini. Proc Natl Acad Sci USA 99: 2038-2042.

Wojnicka-Póltorak, A., W. Prus-Glowacki, K. CELIŃsKi and A. KorczyK (2013): Genetic aspects of age dynamics of a natural Picea abies (L.) Karst. population in the Białowieża Primeval Forest, Poland. New For 44: 811-825.

WRIGHT, S. (1978): Evolution and the genetics of populations. Vol 4. Variability within and among natural populations. Chicago, USA: University of Chicago Press.

Yazdani, R., I. Scotti, G. Jansson, C. Plomion and G. MATHuR (2003): Inheritance and diversity of simple sequence repeat (SSR) microsatellite markers in various families of Picea abies. Hereditas 138: 219-227.

YeH, F. C., R.-C. YANG and T. Boyle (1999): POPGENE version 1.31 - Microsoft Windowsbased freeware for population genetic analysis. Edmonton, Canada: University of Alberta. https:/www.ualberta.ca/ fyeh/popgene.html. 